\title{
Teachers' Evaluation of KBSM Form 4, 5 English Textbooks Used in the Secondary Schools in Penang, Malaysia
}

\author{
Hooi Shyan Khoo (Corresponding author) \\ School of Education, University of Nottingham, Jubilee Campus, Wollaton Road, NG8 1BB, United Kingdom \\ E-mail: invizigoid@gmail.com \\ Paul Knight \\ School of Education, University of Nottingham, Jubilee Campus, Wollaton Road, NG8 1BB, United Kingdom \\ E-mail: Paul.Knight@nottingham.ac.uk
}

Doi:10.7575/aiac.alls.v.6n.4p.128

URL: http://dx.doi.org/10.7575/aiac.alls.v.6n.4p.128
Received: 03/04/2015

Accepted: 06/06/2015

\begin{abstract}
This is an exploratory study of the suitability of Form 4, 5 KBSM English textbooks used in Penang public secondary schools, Malaysia. It aims to investigate the relevance of the current textbooks to the needs of learners and the requirement of public examinations. A checklist is used to gauge teachers' viewpoints while subsequent interview sessions seek to reveal more insightful responses.
\end{abstract}

Keywords: KBSM - Kurikulum Bersepadu Sekolah Menengah (The Integrated Secondary School Curriculum), SPM Sijil Pelajaran Malaysia (High School Certificate), ESL - English as a Second Language, EFL - English as a Foreign Language, ELT - English Language Teaching

\section{Introduction}

Materials for language learning have been defined by Tomlinson (2012) as almost any instrument that aids the learning of a language, be it course books, videos, graded readers, flash cards, games, websites or mobile phone interactions. Course books or textbooks have long been regarded in the literature as the anchors of language pedagogy. Ur (1999) has described them as books to be followed systematically by teachers and students in the process of teaching and learning. The extensive utilization of textbooks across a wide spectrum of ELT contexts has propelled their importance in ELT classrooms around the world (Hutchinson and Torres, 1994; McGrath, 2006; Sheldon, 1988; Swales, 1990). Despite of the emergence of new teaching methodologies and technological advancements, textbooks remain unwavering in their significance in language classrooms (Cunningsworth, 1995; Mukundan \& Rezvani Kalajahi, 2013; Sheldon, 1988; Tomlinson, 2011).

With textbooks being a vital element in leaners' attainment of language, choosing the right one through its meticulous pre-use, in-use, and post-use analysis and evaluation is of paramount importance (McGrath, 2002; Mukundan, Hajimohammadi \& Nimehchisalem, 2011). Carter and Nunan (2001) have termed evaluation of materials as "the process of measuring the value of learning materials" (Carter \& Nunan, p. 223).

This study is motivated by the desire to evaluate the integrated secondary school curriculum - Kurikulum Bersepadu Sekolah Menengah (KBSM) textbooks used by students who would be sitting for the national examination and subsequently progress to tertiary education. The Form 4 and Form 5 English course books are the designated core textbooks used in public secondary schools for students aged 16-17 (Form 4) and 17-18 (Form 5). Written by Malaysian authors, they are in adherence to the Malaysian curriculum; however, they are thought to be written on writers' intuition and not on empirical studies (Mukundan, 2003; Mukundan \& Rezvani Kalajahi, 2013). In order to be able to ascertain whether the textbooks fulfill students' current needs, evaluation of the course materials is imperative.

\subsection{Purpose and Significance of Research}

In the education ecosystem, wrong materials are capable of producing failed language learners (Mukundan \& Rezvani Kalajahi, 2013; Tomlinson, 2008). This research will not only be informative to curricular designers, it could serve as a reference for policy makers in the Ministry of Education in modifying textbooks (Mukundan \& Rezvani Kalajahi, 2013). It is also crucial for teachers to evaluate textbooks already in use in their teaching-learning contexts, so as to decide on the suitability of the textbook to make adaptations for effective usage in classrooms, which will contribute to students' positive acquisition of the English Language (Mukundan \& Rezvani Kalajahi, 2013).

\subsection{Focus of Research}

In an attempt to examine the quality of textbooks used in Malaysia, a post evaluative study into Form 4 and Form 5 textbooks will be conducted in the Northern region (Penang) with particular interests in the productive skills of speaking and writing. This study aims to obtain data on the suitability of the KBSM textbooks used in the state of 
Penang and the need to review them. A mixed method approach will be used with checklists and interviews. As this is a post-evaluative study of the textbooks, teachers will be requested to complete at least one cycle of using the books.

Surveys will be distributed to 18 Form 4 and 5 English teachers (9 in each form) in 9 randomly selected secondary schools. Data will be collected from two randomly selected schools that typify the three major types of schools (all-girl, all-boy and co-education) for each level to reflect a true proportion of the population. Next, interviews will be conducted with 6 teachers whose responses on the checklists are parallel with the research findings. The responses from the interviews will then be analyzed with adaptation proposed for certain sections of the textbooks. Based on these objectives, the following three research questions will be responded:

Are the textbooks suitable for the current needs of students?

Do the textbooks sufficiently emphasize the two language skills of speaking and writing?

How can the KBSM textbooks be improved?

It is hoped that the evaluation results can help to enhance the effectiveness of the use of the textbook and assist teachers in pinpointing the areas of textbooks that need adaptation and supplementation to achieve desired benefits from its content.

\section{Literature Review}

\subsection{Materials: Definition and Classification}

Throughout history, ESL (English as a Second Language) and EFL (English as a Foreign Language) classrooms have seen the utilization of many kinds of materials (Byrd \& Schuemann, 1991). Other than textbooks, materials like handouts, workbook, various types of realia, drawings, photographs, teacher's guide, computers, CDs, internet resources have been used as tools for knowledge transfer between teachers and students (Bryd \& Schuemann, 1991; McGrath, 2002). According to Tomlinson (1998; 2001; 2011; 2012), just about everything which aids the learning of a language can be categorized as materials. However a finer distinction remains between textbooks, which are designed exclusively for language learning and teaching, from a pile of teaching materials (Byrd \& Schuemann, 1991; McGrath, 2002; Tomlinson, 2011).

Prabhu (1987) hailed textbooks as a set of specifiable pre-constructed framework, which ensure consistency in manifold classroom environments. Sheldon (1988) has likened them to the 'route maps of ELT programme, laying bare its shape, structure, and destination' (p. 238). Byrd \& Schuemann (1991) and O'Neill (1993) viewed textbooks as a compilation of information and learning activities which can guide learners towards the fulfillment of course objectives while Hutchinson \& Torres (1994) believed they are 'organized and pre-packaged sets of teaching/learning materials', either existing on its own or with a package of corresponding workbook, teacher's book and cassettes (p. 328). Generally, the classification of textbooks is between the textbooks and materials or the so called 'package' (Hutchinson \& Torres, 1994). Being laden with such responsibilities, it is not surprising to know that coursebooks usually include all components in language learning and teaching (Tomlinson, 2011). From my viewpoint, if all these conceptions on textbooks are to be taken into consideration, textbooks must tread a narrow path in providing syllabus accorded yet coherent practices for effective teaching and learning.

Tomlinson categorised them into five foci of: i) informative (informing learners about target language use), ii) instructional (guiding the learner in using the language), experiential (providing exposure to the language in use), elicitative (stimulating language use), and iii) exploratory (seeking discoveries about language use) (Tomlinson, 2001; 2012). Other classifications of textbooks include: in-house vs commercially published; core vs supplementary; syllabus required materials vs locally chosen and print vs online.

\subsection{Roles and Advantages of Materials Usage}

The roles of textbooks vary in the diverse environments of ELT (English Language Teaching), their relationship is dependent upon the perceived role of textbooks in the situation: as mandated coursebooks or as supplementation for the curriculum (Cunningsworth, 1995). Fundamentally, textbooks are widely viewed as the provision of systematic and cohesive frameworks for teaching and learning throughout the entire course (Byrd \& Schuemann, 1991; Canniveng \& Martinez, 2003; Cunningsworth, 1995; Harmer, 2001; Hutchinson \& Torres, 1994; McGrath, 2002; O’Neill, 1982;; Tomlinson 2012).

The structure provided by textbooks also frees teachers from the hassle of having to plan materials in every lesson while the less experienced teachers can receive training at the same time (Cunningsworth, 1995; Richards, 1998). This is as publishers equate the role of materials as introducing new teaching methodologies to teachers (Edge \& Wharton, 1998; Richards, 1998). It is not unusual to see teaching manuals being laden with activities and language teaching approaches based on the current trends of "approved" pedagogical models (Richards, 1998, p. 128). Nevertheless, its pedagogical role can only be fulfilled when teachers' guides have sufficient information on procedures and explanations on proposed activities (Crawford, 2002).

Textbooks have been embroiled in the highly debatable roles of materials proposed by Allwright (1981); the 'deficiency' view and the 'difference' view (p. 6). In the deficiency view, textbooks are seen to fulfill the role of rectification to the perceived weakness of teachers. The presence of textbooks can ensure lessons are taught according to the syllabus with well-constructed exercises. At the extreme end of this stance, textbooks will not contribute much in the presence of good teachers while 'teacher-proof' materials will prevent bad teaching in class. On the contrary, 
proponents of difference view materials as 'carriers' of language intake information and have the role of imparting knowledge to the rest of the class. Here materials and teachers are seen to have separate yet complementary roles. Nonetheless, critics consider this perception 'reducing' in sidelining the role of teacher to a mere classroom manager while others think it liberates the teacher from having to strain through the tedious task of developing materials for every lesson.

Ready-made textbooks are observed to facilitate participants to learn within the specified objectives while providing a sense of security and autonomy to the learners (Cunningsworth, 1995; Crawford, 2002; Richards, 1998). In some books, students' cognitive skills and metalinguistic understanding are targeted for development alongside with second language learning, in what's termed as 'learner awareness' by Brewster and Ellis (2002). In their view of textbooks as agent(s) for change, Hutchinson and Torres (1994) called for the inclusion of self-directed learning strategies to foster autonomous learning strategies in students. This idea of coursebooks being learning-how-to-learn guides is also much supported by Allwright (1981). Without materials, students are observed to place more emphasis on the teacher as the sole supplier of language intake (Ur, 1996). It can be seen that through the activities of communicative interaction and language references presented in the materials, students' responsibilities towards their learning and their sense of autonomy are further cultivated (Crawford, 2002; Richards, 1998).

\subsection{Disadvantages of Using Coursebooks}

Despite the extensive adoption of materials in ELT worldwide and their perceived superiority over teacher-produced materials, they are not without their criticism. Among the most consistent criticism is their inability to meet the distinctive needs and wants of all their users (Allwright, 1981; Ansary \& Babaii, 2002; Maley, 1998; Richards, 1998; Sheldon, 1988; Tomlinson, 2001; Tomlinson, 2012). This is due to the increased demand for situational specific textbooks that can fit particular requirements (Maley, 1998; Richards, 1998). Global textbooks have often times be seen as irrelevant, culturally inappropriate, incompatible with the latest teaching methodology, of mixed levels and just generally fail to match the diverse needs of their wide range of audience. Tomlinson (2010) even goes as far as saying textbooks, in wanting to appease the teachers and administrators, ignore the needs and wants of those who require it most - the learners. Nevertheless, the issue of mismatched needs could be assuaged by the sharing of core language framework, which learners from diverse backgrounds (lower than advanced level) would need to learn (Crawford, 2002; Freebairn, 2000; O'Neill, 1982;). Most textbooks would have a section in fundamental linguistic contents to provide for learners' basic needs. Since no materials can ever satisfy needs from all quarters and commercial materials are available in large quantities, teachers can always be selective and informed in adapting, supplementing or replacing the materials with better ones.

Another argument against textbooks is that textbooks 'de-skill' the teachers (Allwright, 1981; Canniveng \& Martinez, 2003; Cunningsworth, 1984; Cunningsworth, 1995; Edge \& Wharton, 1998; Freebairn, 2000; Hutchinson \& Torres, 1994; Maley, 1998; Richards, 1998; Swan, 1992; Tomlinson, 2001; Tomlinson, 2012). Opponents argued that textbooks impose too much authority over lessons and constrain teachers in terms of syllabus selection, teaching methodologies and other pedagogical decision-making in turn marginalizing teachers to superficial figures in the learning/teaching process. As a consequence, teachers are impeded in their professional development while becoming mechanical in their teaching procedure, language usage and in responding to students' needs. It can also create a phenomenon of coursebook dependance, especially among inexperienced teachers (Canniveng \& Martinez, 2003; Chandran, 2003; Richards, 1998). Further adding to it is the dilemma of reification, a tendency often supported by the promotional efforts of publishers' (Richards, 1998, p. 131). The view illustrated the reality of some teachers' deep-rooted reverence towards printed materials and their reluctance to deviate from the lesson structure set out in the book subsequently trivializing their contribution in class.

There are concerns that coursebooks are reductionist and compromised in its representation of language (Freebairn, 2000; Richards, 1998; Thornbury, 2000; Tomlinson, 2001, 2012). The homogenous and contrived world devoid of emotions in the world of coursebooks fail to engage learners as it did not tap into the 'affect' segment in learning (Tomlinson, 2012). Nevertheless, this issue could be solved by the 'humanising coursebook' approach of aesthetically engaging learners to learn in a friendly environment advocated by Tomlinson (2003).

Taking account of all the deficiencies possessed by textbooks, it is justifiable for teachers to look into alternatives, namely locally produced materials (Harmer, 2001). Such a textbook free approach could provide learners with what material writers have been struggling to give - a personalized, relevant and engaging experience of language in use which will greatly raise their motivation (Harmer, 2001; Tomlinson, 2003). However for teachers to be skilled in materials preparation, they will need to have access to a wide range of materials; experience and confidence in choosing the right bit of information to include, in addition to ensure it does not diverge from the curriculum. Daunting as it sounds, teachers also need sufficient time to complete the task while running the risk of materials falling into incoherent bits and pieces of exercises (Harmer, 2001). However, not all teachers can be material designers and to prepare teachers for that they need to be supported in training (Richards, 2012; Tomlinson, 2003). Finally, teacher-produced materials will not be as visually appealing as commercial materials and many teachers still have neither expertise nor access to adequate technology to create 'authentic' audiovisual materials (Crawford, 2002; Richards, 2012).

In any case, teachers and students still have much to gain from textbooks. Their very existence proves that despite their shortcomings, alternatives like teacher-produced materials are still no match for them. With the emergence of more localized textbooks - easily altered commercial textbooks with web-based suggestions for modification and replacement, textbooks have done much in minimizing their negative impact in the ELT circle. 


\subsection{Evaluation Cycle}

After contending on the multiple situational needs a textbook has to fulfill, careful analyses and evaluation must be exercised prior to textbook selection. Textbooks are generally evaluated for two major reasons: i) to pick a new coursebook for the programme or ii) to perfect its usage in the existing material (Cunningsworth, 1995; McDonogh \& Shaw, 2003; Sheldon, 1988).

Cunningsworth (1995) listed two other considerations for textbooks evaluation: evaluation for potential and evaluation for suitability. Evaluation for potential will entail the evaluation of a new book without having to consider the learners while suitability pertains to matching the coursebooks against a specific set of criteria. Inevitably, evaluation will entail elements of comparison between textbook materials and their effectiveness in learners using them (Tomlinson, 2008).

As stated by McGrath (2002) and Tomlinson (2003; 2012), there is a noteworthy distinction between analysis and evaluation. The "analysis" encompasses the providence of an "objective, verifiable description" (McGrath, 2002, p. 22) whereas "evaluation" serves to include context-related factors in comparing the description of a textbook. Hence, evaluation is analysis with context. Since evaluation is influenced by learners and context, it is of a subjective nature (Tomlinson, 2012).

The framework suggested by McGrath (2002) theorizes that analysis precedes evaluation with needs analysis and context analysis. Needs analysis is explained as a subjective analysis of a learner's needs (Cunningsworth, 1983) while context analysis can be categorized into macro and micro analyses. The macro stage would take into account the aims of education, language policy and the textbooks' role within the country; the aims of language education within cultural, religious considerations (McGrath, 2002). Micro level, on the other hand, involves the group of users who will come into contact with the materials, be it an institution, a programme, teachers or learners (McGrath, 2002).

From the classification above, the evaluation versus analysis framework can be illustrated in the following three-stage format:

Textbook analysis $\rightarrow$ needs analysis + context analysis (macro $\&$ micro) $=$ evaluation

Pertaining to the explanation by Ellis (1997) and McGrath (2002), there are three main stages of evaluation: pre-use (predictive), in-use (immediate) and post-use (retrospective). Widely believed to be the most difficult type, pre-use evaluation seeks to examine the suitability of a textbook prior to it being used in a programme. The evaluation of material pre-use is vital for teachers and administrators to gauge the performance of a textbook in the target context. Next, in-use evaluation is the evaluation of textbook currently being used. It can be used to monitor the suitability of a textbook in meeting learners' needs or a program's objectives. Additionally, it has the benefit of revealing insights into ways teachers use materials (Richards and Mohoney, 1996 as cited in McGrath, 2002). This can garner suggestions for materials development in the future. As the name suggests, post-use evaluation involves the assessment of a textbook after it has been used in a full cycle of a course. Among the strong proponents of post-use evaluation, Ellis (1996), Masuhara (2011) and Tomlinson (2003) express the importance of undertaking such an evaluation, as it shows both short- and long- term effects while providing teachers with information on ways to modify them for repeated usage.

According to McGrath (2002), there are three distinct methods of textbook evaluation: i) impressionistic, checklistbased and in-depth analysis. Impressionistic is the preliminary evaluation, the 'quick look' through a coursebook's structure and design whereas the checklist method entails a systematic evaluation of instructional materials based on a specific set of criteria while in-depth analysis requires a more detailed inspection into the learners' needs, learning styles preferences, implications of using the materials and on the teachers' experience and beliefs about language learning and teaching. Out of the three, the checklist method will be the most feasible in context where time is limited (Mukundan \& Nimechisalem, 2012).

\subsection{Checklist Evaluation}

McGrath (2002) listed four advantages of using the checklist method: it is systematic, cost effective, information gets to be recorded in a convenient format, and it is explicit in content. However in selecting the suitable textbook, attention should be paid to ensure analysts do not detract from the neutral, value-free systematic approach of analysis to the generalizations based on personal preferences. Consequently, a checklist that is objective, comprehensive in its evaluative criteria, discrete in its description of characteristics should be utilized (Tucker, 1978 as cited in Tomlinson, 2003).

Given the convenience checklists provide, numerous well-designed ones have been conceived by textbook evaluation theorists and practitioners, such as Cunningsworth (1995); Harmer (2001); McDonough \& Shaw (2003); Miekley, (2005); Mukundan Hajimohammadi \& Nimehchisalem (2011); Skierso (1991); Sheldon (1988); Tucker (1975). Although many checklists have been utilized in ELT textbook evaluation, there is still a limited supply of literature on the extent of its popularity (Sheldon, 1988).

To facilitate the evaluation process, the criteria in checklists need to be well developed (Mukundan \& Ahour, 2010). According to McGrath (2002), the specification of criteria is posited on the well laid out assumptions of learners, teachers and contexts as the end users. The criteria are commonly divided into groups of general or specific, with general shaping the latter. However as evaluation is influenced by context, the formulation of evaluative criteria will be affected by current teaching methodologies as well as the needs of users.

Of the varying checklists that were published, there is a commonality in their broad areas of evaluative characteristics (McGrath, 2002; Mukundan, Nimehchisalem \& Hajimohammadi, 2011). They were mostly referenced in the aspects of 
physical layout, language content, learning objectives, methodology and practical considerations (Ansary \& Babaii, 2002; McGrath, 2002; Mukundan \& Ahour, 2010). Clearly, securing a suitable checklist is crucial in textbook evaluation, but in order for it to be effective, certain guidelines must be followed. As creating a new checklist would be very time consuming, it would be more practical to adapt a ready-made checklist to suit the current requirements, a move much encouraged by McGrath (2002) in his approach of stocktaking, tailoring and evaluating.

\subsection{Criticism in Checklist Evaluation}

Inevitably, the method of checklist evaluation has criticism amidst its advantages. One persistent complaint is its subjectivity as human analysts are relied on in a supposedly neutral measurement of the qualities of materials. As stated by McGrath (2002), the nature of evaluation is value laden with context-influenced assumptions formed by analysts while some categories proved difficult to quantify. A viewpoint well illustrated by Sheldon (1988) 'it is clear that coursebook assessment is fundamentally a subjective, rule-of-thumb activity, and that no neat formula, grid or system will ever provide a definite yardstick' (p. 245). However by opting for retrospective or post-use evaluation, the findings can better inform analysts of the outcome on using the materials (Canniveng \& Martinez, 2003; Ellis, 1997).

There is also the concern over the decreased credibility and relevance to a target context in an inadequately adapted or designed checklist (McGrath, 2002). Opponents counter that checklist criteria and key questions are influenced by the 'swings of linguistic fashion' that can result in the change of interpretation in the criteria along with the rating assigned to each category (Riazi, 2003). In my view, this limitation can be compensated by assimilating a comprehensive textbook analysis (e.g. the frameworks by Littlejohn, 1998; McDonough \& Shaw 2003; McGrath, 2002) or employing material piloting after or before the use of the checklist method. As the categories in each checklist are "emphatically local' with the task of assessing superiority of one checklist over another time consuming, it can be inferred that there is no checklist that 'best-fit' all situational needs in every teaching contexts (Mukundan and Ahour, 2010; Sheldon, 1988).

\section{Methodology}

\subsection{Sampling Methods}

The designated textbooks of Forms 4 and 5 published in 2002 by PGI Cipta Publications \& Distributors Malaysia will be analyzed for their suitability towards the current needs of students, in conjunction with the need to review them and how they fall in place with the productive skills of speaking and writing.

For this purpose a mixed method approach of quantitative and qualitative nature is applied with checklist and interview being adopted as the mode of research. The implementation sequence will be based on the sequential transformative design of 'Quan $\rightarrow$ qual $\rightarrow$ qual' (Creswell, 2003). The strategy is characterized by the development nature of the initial quantitative method to the subsequent qualitative ones. The checklist (quantitative) will inform the development of the subsequent rounds of interview (qualitative). Each step however is given equal priority with the eventual aim of forming an inferential assessment based on the data that may emerge. The mixed-methods model is chosen due to its ability in getting access to both types of research methods; one being the objective scored responses from a larger number of participants, second being the in-depth information gathered from a smaller sample of individuals. The corroboration of results from different sets of findings can well substantiate, confirm and strengthen the claims that may emerge (Creswell, 2003; Dörnyei, 2007). Other than that, an enhanced understanding can be achieved from the wider scope of study through the different methods adopted (Dörnyei, 2007).

\subsection{Sampling Procedures}

As emphasized by Mukundan, Nimehchisalem \& Hajimohammadi (2011) on the "valid and reliable instrument", a modified checklist developed by Mukundan, \& Nimehchisalem (2012) and interview questions sourced from Cunningsworth (1983) and Sheldon (1988) are utilized (Please refer to Appendixes A). A checklist created by Mukundan \& Nimechisalem (2012) is chosen as the tool for systematic evaluation due to the superior key qualities it possessed, refer to point 3.3 for further elaboration. The checklist will be administered to 18 teachers from 9 randomly selected public secondary schools out of a list of 89 schools (the total number of national secondary schools in Penang). The results therewith will be analyzed with the intention of themes identification. Six teachers whose responses are representative of the themes identified will be singled out for interviews. At the interview session, 15 questions sourced from Cunningsworth (1984) and Sheldon (1988) will be used to gather richer information from the teachers.

\subsection{Evaluation Through Checklist and Interview}

A checklist developed and refined by Mukundan \& Nimechisalem (2012) will be chosen as the tool for systematic evaluation (see Appendix A for the checklist). The checklist is comprehensive in its evaluative criteria as it was developed after an extensive evaluation of 48 checklists. It has also been constructed in Malaysia which fits the context of this study. Published in 2011, the checklist has been put to stringent tests and refinement, beginning with a focus group study which includes Malaysian teachers within the country's education setting followed by a quantitative examination of each item's level of importance. This checklist has also been proved to be of high validity (it has been approved by 207 ESL experts), economy (shorter time needed to complete the checklist) and reliability in its design with all items being found to be of equal importance (Mukundan \& Nimechisalem 2012). As the checklist is constructed and tested recently with the content and assumptions of language teaching and the depiction of society befit this study the Malaysian education background; it is adopted with no alterations made. This is also to avoid the exclusion of certain important questions and the inclusion of trivial questions, which could create a less effective evaluation (McGrath, 2002). 
The materials' evaluation criteria required respondents to indicate the levels of importance with 0 being unimportant and 4 very important. The 5-point Likert scale is assigned to provide more points of discrimination for more precise evaluation results. Although there remains the inclination towards the mid-point answers, the respondents can be informed of the problem and be advised to avoid it (Mukundan, Hajimohammadi, Nimehchisalem, 2011).

The evaluation assessed the materials in relation to the following areas:

- General Attributes in relation to syllabus and curriculum

- Methodology

- Suitability to learners

- Physical and Utilitarian Attributes

- Efficient outlay of supplementary materials

- Learning-teaching content (General features, listening, speaking, reading, writing, vocabulary, grammar, pronunciation and exercises)

\subsubsection{Interview Questions}

The interview questions are of emergent rather than predetermined as the researcher learned of the data and formed broad themes from the checklist analysis. The general pattern of questioning is sourced from the two checklists constructed by Cunningsworth (1995) and Sheldon (1988) due to the questions' relevance to the research context. Tomlinson (2012) had applauded Cunningsworth (1995) for providing a very detailed checklist 'for evaluating teaching material' (p.74) while Sheldon's efforts $(1987,1988)$ in both evaluating and developing textbook material were deemed commendable. However as the evaluation criteria in the questionnaires above are specific to contexts which they are intended for, the questions are not quite relevant to the current situational needs of this study (Cunningsworth, 1995; Sheldon, 1988; Tomlinson, 2003 and Tomlinson, 2012). Therefore the questions are modified to suit the context of this study. As there is no teacher's book, questions will not be asked on that particular topic.

As proposed by McGrath (2002) and Tomlinson (2003, 2012), the interview questions are formed from a few general 'principled' categories selected from the main checklist - Mukundan \& Nimechisalem (2012) and from the two checklists developed by Cunningsworth (1995) and Sheldon (1988). The general criteria are determined based on the textbooks' suitability to students' current needs in accordance with the requirements of the official syllabus. The general categories are methodology, utilitarian, sufficiency, efficient outlay of materials, suitability to learners, learningteaching content, speaking, writing, listening, role of teacher and suggestions of improvement. From the general criteria, specific questions are further developed.

The question format has been kept, as the interview session is intended to elicit richer information from participants to complement the questionnaire data. The open-ended line of questioning will seek to draw in opinions in an attempt to get more insights into the phenomena and to increase the credibility of the findings (Creswell, 2003). Please refer to appendix B for a detailed explanation on the formation of interview questions.

\subsubsection{Pilot Study}

Piloting of research tools should ideally be performed before the actual phase of data collection (Creswell, 2003; Dörnyei, 2007; McGrath, 2002; Paltridge \& Phakiti, 2010). This is to allow for the fine-tuning of questions to a particular context by either the researcher or another person (McGrath, 2002).

The assigned checklist was being tested out on a familiar textbook (Form 5) by the author to assess any discrepancy in the questions. This was to test the relevance of the different criteria in the current context, along with the interpretation given to the scores assigned in each category. The questions were found to fit the requirement of the evaluation criteria. The guidelines proposed by Tomlinson \& Masuhara (2004) on clarity, conciseness, free of dogma, and reliability in that other participants would not interpret them in a different way were being referred to while the checklist was being evaluated with a known textbook. After some scrutinization, the questions were found to be relevant with no need of revision.

Similar to the checklist, the interview questions were being piloted for reliability purposes. This was to test the objectivity of the questions and to clarify any ambiguities that may appear. A Malaysian secondary school English teacher (non-research participant) was enlisted to assist in the trial interview with questions being asked in the exact wording as they were constructed, following the advice of Brown (2001). No amendment was made to the interview questions as the questions were found to be clearly worded and suitable by the teacher.

\section{Results and Discussion}

\subsection{General Attributes}

The textbooks were both found to match most specifications of the syllabus. This is due to the fact that the textbooks were being written to adhere to the Malaysian curriculum and were designated core textbooks for both Forms. However ever since the introduction of 'Short Texts and Graphic Materials' and 'Rational Cloze' in Paper 2 of the national examination SPM English paper, the textbooks haven't been adapted to provide practice for students. Teachers, especially Form 5 teachers, whose students will be sitting for the national examination at the end of school year, have had to supplement materials in these two sections to cater to students' needs. Despite this flaw, Form 5 textbook was graded to be highly compatible with the curriculum while Form 4 was slightly lower in grading, although still within the 
scale of high compatibility. The lower grade responses were given by teachers who had low proficiency students. The students could not comprehend much less complete the exercises from the book. Those group of teachers had commented that they supplemented the textbook with easier materials sourced from commercially published reference books. The findings are in line with those of Chandran (2003) and Asiah Abu Samah (1984), whose previous researches revealed the level of language in the textbooks exceeded the standard of some students.

\subsection{Methodology}

As delineated by the authors of the textbooks, the usage of language has been shaped around the three principal ways of interpersonal, informational and aesthetic forms of language learning (Chitravelu, et al. 2005). Students are encouraged to socialise (interpersonal), to acquire knowledge (informational), to think and to enjoy the creative side of the language (aesthetic). Overall, teachers from both levels were satisfied with the methodology adopted in the book, which was deduced to be Theme Based Instruction within the Communicative Language framework. Form 5 teachers marked the methodology as highly favourable, they were presumed to be able to exploit and embrace the various methodologies in ELT as well as with corresponding activities. Although the scores were as fairly favourable as the Form 5 ones, there were some Form 4 teachers who found the activities limiting and difficult for some of their students. This was due to the demand of proficiency needed for students to complete the exercises which was not achievable in the teacher's class.

\subsection{Suitability to Learners}

The textbooks have been found to suit the age of learners and their needs, although more so with the form 5 students than with form 4 . The scale was highly favourable for form 5 teachers while moderately favourable for form 4 teachers. Similar to the responses given earlier, the Form 4 textbook exceeded the level of some students with teachers having to simplify and adapt the contents of the book, as per Gibbons' idea of scaffolding (2002).

\subsection{Physical and Utilitarian Attributes}

This component received a highly favourable rating from Form 5 teachers and moderately favourable rating from Form 4 teachers who found the 256-paged glossy textbook to be clear, attractive in layout, durable, cost effective with efficient use of text and visuals. From the general opinion of teachers, the layout and design of the textbook was seen as structured with clarity and consistency shown in every unit. A typical chapter would consist of a theme related conversational practice, followed by listening and speaking, reading, vocabulary, phonemes, grammar exercises and writing. Though the controlled practice activities with cohesive learning tasks could be conducive for classroom learning environment, it could also be dull and too rigid for some Form 4 learners as commented by their teachers. Both groups of teachers thought that instructions given for the activities were clear and the page design relatively uncluttered. Such clear structure aided instruction for the teachers and encouraged exploratory learning within each topic for the learners, as suggested by Piaget in the theory of language discovery (Jardine, 2006). Both textbooks were not short of visuals with pictures and graphics found in nearly every page of the book. Yet some Form 4 teachers remarked that the pictures were too 'pat' and 'contrived'. Suggestions were thrown in on having comic strips or animated pictures so as to lessen students' boredom during lessons. However, the simple illustrations allow for "white space" which could engage learners' interest without distracting them from the learning objectives of the task (Tomlinson et al, 2001). In the matter of cost efficiency, the KBSM textbooks are available free on loan in all government schools. However, for students who did not qualify for the textbook loan scheme, the Form 5 textbook cost a steep RM19.10 while the Form 4 cost RM13.90. It was due to these pricing that some Form 4 teachers gave this criteria a low grade. When it comes to durability, Form 4 teachers had higher complaints than their Form 5 counterparts. They needed a hard back textbook, preferably with covers that repel water and stronger binding as books get easily damaged when wet.

\subsection{Efficient Outlay of Supplementary Materials}

In this section, Form 5 teachers gave a favourable rating while the scores were moderate for the Form 4 teachers. The greatest concern is that there is no teacher's book and in some cases, no audio CDs to supplement the learning tasks in the book. Teachers had commented that they had to formulate their own answers and lend their voices or sometimes the students' as the source of listening in the classrooms. This could lead to inaccurate modelling and use of English in the classrooms.

\subsection{Learning-teaching Content}

In this section, a general picture of teachers' perceptions on the learning-teaching content and the four language skills of listening, speaking, reading and writing will be clarified. In the introduction of the textbook, it is stated that activities within each chapter are graded at three levels to meet the needs of students with different abilities, interests and learning styles (Lee, et al. 2013). With reference to the survey results, Form 5 teachers gave a highly favourable score of 3 as compared to the moderately favourable responses from Form 4 teachers. While some teachers revealed their unawareness of the tasks grading, some shared that the indicator wasn't made explicit in the textbooks. It's interesting to note that for the teachers who knew of its existence, they rendered it 'pointless' as it did not assist them in any way. According to the respondents being interviewed, the grading scheme can be improved in having tasks which actually reflect the levels they represent. For example in the reading component, there can be different sets of questions in accordance with the grading schemes of easy, moderate and difficult. Not only will it be more flexible, it will also be more practical for teachers with students of mixed proficiency levels. With this, teachers will no longer have to go through the trouble of sourcing the right level reference materials to supplement or adapt the tasks in the textbooks. Still on the topic of learning-teaching content, all teachers gave a highly favourable score for the rest of the questions in the 
checklist. They thought that the task objectives are mostly achievable with cultural sensitivities having been taken into account. Authenticity wise, the language in the textbook is natural and real with the situations created in the dialogues sounding natural and real. This can be seen in the depiction of Malaysian names (e.g. Jefri, Nek, Munah, Ballang, Shan, Azman etc.), the usage of the Malaysian currency Ringgit, local addresses, telephone numbers, street names, hotel locations in different states of Malaysia (Melaka, Kuala Lumpur, Terengganu, Pulau Tioman) the mention of the major ethnicities in the country (Malay, Indian, Chinese, Kadazan, Dayak and Iban), the introduction of Malay words in the text (satay, ketupat, gunung, keris), local celebrations like Hari Raya, Chinese New Year, Hari Gawai, Deepavali and Christmas to the description used in some reading passages 'she has langsat-yellow skin, a typical Malay beauty'. It would seem that Malaysian culture is prevalent in both the theoretical and practical frameworks of the book. However, teachers interviewed complained of the 'boring' content which had students learning environmental subject of rain, occupations of being a nurse or a pilot, ways to lead a healthy lifestyle among others.

It is the norm for a chapter in both textbooks to start off with the listening component which serves to introduce the chapter to the students. In the 'Tune in' section, students are required to perform certain tasks related with the 'briefing' they heard. For the subsequent listening activity, they will either have to listen and speak or listen for further instructions to complete tasks with corresponding pictures. With listening occupying a mere 2 pages out of the normally 16-page content in a single chapter, it would appear that listening has the smallest portion of exercises. Teachers at both levels rated this section highly favourable as both books have appropriate listening tasks in accordance with welldefined specifications laid out in the syllabus. There are also tape scripts that students can refer to at the back of the book for additional practice. On the issue of authenticity in the speech articulated in the audio CD, most teachers thought that it is close to real language situations although they couldn't come to an agreement on the type of accent used in the recording. To some, the actors sounded like non-accented Malaysians while others thought they were speakers from other nationalities. Regardless of the difference in opinions, the listening section is deemed adequate by most of the teachers surveyed although it will be better to include accents from different nationalities of native speakers in the listening practice so students can familiarize themselves to the diverse speaking styles.

The speaking section received an average rating of 'highly favourable' from both groups of teachers. Speaking activities appear to fit the description of initiating meaningful communication and are balanced between individual response, pair work and group work. They allow plenty of practices throughout the chapter in forms of 'pair work', 'topic description', 'poem recital', 'responses to social situations', 'pronunciation' and 'tongue twister'. Regrettably, some teachers interviewed remarked on the 'boring' topics (e.g. usage of computers, drafting a school newsletter, pros and cons of building a dam among others) with unclear instructions for task implementation and the lack of variety in tasks, as they are mostly restricted to role play or group discussion. Teachers have put forward some suggestions to remedy this situation, first is to have topics of interests or photos which can relate to students' experience and engage them in thoughtful conversation. Second is to have a balance range of speaking tasks to enable students to practise in different enacted transactional and interpersonal situations. For example, a learner can practise monologues in story telling, justifying a decision or be in groups for free discussion. Other than that, some light-hearted activities like guessing games, jigsaw tasks, ranking exercises can also be added to stimulate spontaneous interaction. As contended by Savignon (2001), real life communication entails the integration of language, setting and target language culture. Therefore, successful communication would require some form of understanding in the cultural context of the target language. As such, textbooks should assume the responsibilities of providing appropriate cultural settings where speaking prompts are introduced with clear instructions in a variety of formats with engaging content.

For reading, both groups of teachers gave a similar score of highly favourable. They thought that most of the texts are decent and students can connect to the texts. However, for certain teachers, they have to supplement this component with a shorter reading passage and simpler corresponding tasks due to time constraint. The interviewed teachers also shared that the texts and corresponding activities could be lengthy at times.

In the writing section, most of the teachers in Form 4 and 5 rated it highly favourable. The writing tasks are designed to have achievable goals and take into consideration learner capabilities. Some teachers have commended the writing section, praising its process writing approach in guiding students to write in accordance with the national examination format. However it is without any weakness. It is worthy to note that the scaffolding provided is insufficient to weaker students while high proficiency students find the activities dull with no interesting words or phrases. Teachers have responded that there needs to be more scaffolding provided to students, especially the weak ones. As most teachers follow a linear sequence of teaching writing: planning, drafting and revising, the scaffold of sentence formation with step-by-step guide to paragraph composition will prove a valuable support to students struggling with the writing process. However, clear instructions are still needed to guide students in planning and organising essential information that they generated. Students in a sense are not fully mature as writers, in order to help them build up on competence, they have to develop a sense of audience (Hedge, 2000). This can be achieved by creating audiences in the textbooks, for example students can write for real audiences such as local organisations or individuals, class magazines could be put on notice board for a wider readership consisting of school community or students could write in pairs where work in one student's writing forms the basis for a response from the other student. Writing exchanges as such truly reflect the interaction of reading and writing in real life.

The vocabulary and grammar section of the textbooks received a highly favourable rating from most of the teachers surveyed. This is due to the fact that the vocabulary is in accordance with the list of vocabularies which will be tested in the public examination while the spread of grammar is achievable, contextualized with examples introduced explicitly. 
There is also an appropriate load of vocabulary in accordance with the level, a good distribution (simple to complex) of vocabularies across the chapters and the whole book. Nonetheless, it was found to be somewhat lacking when it comes to recycling and repeating new words and grammar items in subsequent chapters to encourage their retention. Responses gathered from teachers revealed that this is the section where they have to supplement the most due to the inadequate allocation of exercises and the limited explanation provided for grammar items.

From the data gathered, both groups of teachers rated the exercises component highly favourable. The exercises are deemed learner friendly, adequate and can be catered to students who are under or over-achievers. Teachers commented that it is up to their discretion to fully utilize the practices to suit students of different proficiency levels. The textbook authors, aware of how prolonged classroom sessions can be, provided a plethora of multimedia activities under the 'ICT Skills: Stretch Yourself' section. It comprises internet search, internet for research, online library research, online letters to newspaper editor, creating an email account among others. Teachers welcome this section as students get to apply what they have learned in a series of reinforcement activities in the computer laboratory. Most exercises are presented using a top-down strategy with partial emphasis on the multiple intelligences except for bodily - kinesthetic.

As literature section is incorporated in the book and will contribute some questions to the public examination, the component is included for discussion. Teachers have highlighted the need for an updated section since its introduction in 2003 due to the multiple changes in the examination format in 2009. The teachers interviewed are in favour of the literature section, however it needs to be updated to suit the current examination needs and be more creative in its content.

\subsection{Comparison with Previous Researches}

The results are consistent with those of the quantitative study done by Mukundan and Rezvani Kalajahi in 2013. Similarly, both textbooks are graded 'moderately useful' by teachers in a scale of negligible usefulness to very high usefulness.

Other areas like compatibility to the examination syllabus, layout of textbooks are reflected in the findings by Chandran (2003). From his interviews of sixty junior and senior teachers from various states in Malaysia on their attitudes and perception of the current textbook use, many responded that the current textbooks were unable to meet the needs of learners to prepare them for the national examination while the layout of materials were considered dull; they were also thought to be too difficult especially with the merged literature section. Many teachers shared that they did not use the textbooks wholly and chose to supplement them with commercial reference books, which they found to be more appropriate and interesting. This is also the case for the teachers interviewed in this study.

Overall, the materials provide adequate opportunities for practicing the four language skills of reading, writing, listening and speaking. However, modifications are needed for them to move away from the notoriety of being 'boring relics'. In view of the changes brought forth by the Malaysian Examination Council (MEC) five years ago, the textbooks need to be updated with the current trends of examination requirements. Secondly, the textbooks placed much reliance on teachers in conducting the activities in the book, very much so that a teacher described the state of students without the presence of their teachers as 'crippled'. In the sense that these are higher level secondary school students, autonomous learning must be encouraged and reflected in the activities found in the textbooks. The reorientation of a teacher's role is necessary for the learners to move away from the stance of passivity and dependence to undertaking responsibility in their learning for a more effective mastery of the target language (Hedge, 2000). Material writers could include systematic techniques for independent learning in exercises alongside cognitive and metacognitive strategies to enhance learning. Thirdly, there needs to be a solution for students who are on the loan book scheme who could not write on the book pages as the books must be returned at the end of each school year. In trying to minimize students' workload in having to copy down the questions and answers, some teachers resort to photocopying supplementary materials.

The rest of the suggested modifications have been outlined in the earlier paragraphs, here is a summary of the points mentioned:

i) to provide teachers with teaching guidebooks as well as CDs (for certain schools);

ii) to have a clearer grading scheme for the three levels of difficulty (easy, medium and hard) and to have tasks which actually reflect the grading with a range of activities for teachers to choose from depending on the levels of students;

iii) the inclusion of a more diverse range of registers and accents used in the audio readings;

iv) more scaffolding provided to students in writing;

v) more exercises on vocabulary and grammar;

vi) a revision of content for it to be up-to-date and appealing to learners.

\section{Conclusion and Pedagogical Implications}

This study attempted to evaluate the KBSM textbooks used by Form 4 and Form 5 students and to offer suggestions for them to be used more effectively. The three research questions which were posited earlier will be answered accordingly.

For the first research question: Are the textbooks suitable for the current needs of students?, both the textbooks are found to be moderately suitable to the needs of students. Their most obvious shortcomings are the incompatibility to the current exam format, bland content and the lack of exercises in the linguistic features of grammar and vocabulary. The 
textbooks need to be kept with the latest examination requirements in terms of format while the contents can be more engaging. More practice should also be provided in grammar and vocabulary section.

In the next question of: Do the textbooks sufficiently emphasize the two language skills of speaking and writing? The textbooks are found to be highly suitable in laying the groundwork for the two skills of speaking and writing although with some drawbacks. Speaking could use a wider range of tasks with more appealing topics in a meaningful context while the task instructions can be clearer. On the other hand, writing could provide more scaffolding and relate task objectives better to students.

On the final question of: How can the KBSM textbooks be improved? In both textbooks, the deficiencies can be mitigated by the following aspects: i) ensuring teachers are supported with guidebooks and audio CDs, ii) providing teachers with a wider selection of tasks which are level-adapted to the difficulty levels of easy, medium and hard, iii) including foreign speakers and more accents used in audio readings, and iv) applying new words and grammar items learned in subsequent chapters.

Overall, both the Form 4 and Form 5 textbooks received favourable ratings in the checklists, it was only in the interview stage that a number of disapprovals were recorded. It is worthy to note that, although both textbooks are not without their flaws, the deficiencies can be lessened with ample supplementation on the teacher's behalf.

\subsection{Pedagogical Implications}

It is of my belief that the research results have given me an indication for recommendation and suggested course of action to material writers and teachers. In keeping with the results, several suggestions for pedagogical improvements will be highlighted in the following.

First and foremost, publishers could provide a variety of course books for the selection of the schools, allowing flexibility in choosing the course book which will best fit the school. Additionally, material writers could devise ancillary teaching aids to allow more creative freedom to teachers in the classroom. Teaching aids like posters for group discussion, picture cards for pronunciation, tactile objects for story telling could be used to develop the topics in the book further while making learning English enjoyable. Suggestions for enrichment activities as such and steps for conducting them should be laid out in the teacher's guidebook as well as alternatives in expanding or reducing the activities. Ultimately, school authorities should ensure the acquisition of the teachers' guidebooks and the teaching aids from the relevant ministry.

Another point of vital importance is to have trained teachers who are skilled in making full use of the textbooks. Even if teacher training does not support this, additional training programs for teachers can be given periodically in areas of adaptation, supplementation, advice on how to use the textbooks in mixed-ability classes and strategies to encourage vocabulary and grammar retention, depending on the needs of the particular group of teachers. For schools with multimedia laboratories, coaching should be provided to teachers to allow for skillful operation of the ancillary software.

Finally, the National Curriculum Development board could be more responsive in handling feedback from teachers on the issue of textbooks. As the official channel for KBSM textbook evaluation, it could share the vetting results with schools and teachers and have an interactive communication with its end users. Not only does this provide an outlet for teachers to air their grievances on textbook use, the suggestions and complaints gathered could in turn enhanced the usage and subsequent publication of the coursebooks. However, for such plans to be implemented, much cost will be incurred.

\section{References}

Allwright, R. L. (1981). What Do We Want Teaching Materials For? ELT Journal, 36(1), 5-18.

Ansary, H. \& Babaii, E. (2002). Universal Characteristics of EFL/ESL Textbooks: A Step Towards Systematic Textbook Evaluation. The Internet TESL Journal 8(2). Retrieved from http://iteslj.org/Articles/Ansary-Textbooks/ on July 10, 2014.

Brewster, J. \& Ellis, G. (2002). Tell it Again! The New Storytelling Handbook for Primary Teachers. London: Penguin Longman.

Brinton, D. M., Snow, M. A., \& Wesche, M. (Ed.). (2003). Content-Based Second Language Instruction. Michigan: The State of Michigan Press.

Brown, H. D. (2nd ed.). (2001). Teaching by Principles: An Interactive Approach to Language Pedagogy. New York: Longman.

Burns, A. (2010). Doing Action Research in English Language Teaching. A Guide for Practitioners. New York: Routledge.

Byrd, P. \& Schuemann, C. (2013). English as a Second/Foreign Language Textbooks: How to Choose Them-How to Use Them. In M. Celce-Murcia (4 ${ }^{\text {th }}$ ed.), Teaching English as a Second or Foreign Language (pp. 380-393). Heinle \& Heinle Publishers.

Canniveng, C. \& Martinez, M. (2003). Materials Development and Teacher Training. In B. Tomlinson (ed.), Developing Materials for Language Teaching (pp. 479-489). London: Continuum. 
Chandran, S. (2003). Where are the ELT Textbooks? In W.A. Renandya. (Ed.). Methodology and Materials Design in Language Teaching: Current Perceptions and Practices and Their Implications (pp. 161-169). Singapore: RELC Portfolio Series.

Crawford, J. (2002). The Role of Materials in the Language Classroom: Finding the Balance. In J. E. Richards and W.A. Renandya (Eds.), Methodology in Language Teaching: An Anthology of Current Practice (pp. 80-91). Cambridge: Cambridge University Press.

Creswell, J.W. (2nd ed.). (2003). Research Design: Qualitative, Quantitative, and Mixed Methods Approaches. Thousans Oaks, CA:Sage.

Chinniah, W., Soo, T. B. \& Wong, G. (2013). English Bestari. Petaling Jaya: Sasbadi Sdn. Bhd.

Chitravelu, N., Sithamparam, S. \& Teh, S. C. (2nd ed). (2005). ELT Methodology: Principles and Practice. Oxford Fajar Sdn. Bhd.

Cunningsworth, A. (1983). Needs Analysis - A Review of the State of the Art. System, 11(2), 149-154.

Cunningsworth, A. \& Tomlinson, B. (1984). Evaluating \& Selecting EFL Teaching Materials. Oxford: Heinemann.

Cunningsworth, A. (1995). Choosing Your Coursebook. Oxford: Heinemann.

Dörnyei, Z. (2007). Research Methods in Applied Linguistics. Oxford: Oxford University Press.

Edge, J. \& Wharton, S. (1998). Autonomy and Development: Living in the Materials World. In B. Tomlinson (ed.), Developing Materials for Language Teaching (pp.295-310). London: Continuum.

Ellis, R. (1997). The Empirical Evaluation of Language Teaching Materials. ELT Journal, 51(1), 36-42.

Freebairn, I. (2000). The Coursebook - Future Continuous or Past? English Teaching Professional 1(5), 1-6.

Gibbons, P. (2002). Scaffolding Language, Scaffolding Learning: Teaching Second Language Learners in the Mainstream Classroom. Portsmouth, NH: Heinemann.

Harmer, J. (3rd ed.). (2001). The Practice of English Language Teaching. Harlow, Essex: Longman.

Harwood, N. (2010). Issues in Materials Development and Design. In N. Harwood, English Language Teaching Materials: Theory and Practice (pp. 3-32). Cambridge: Cambridge University Press.

Hedge, T. (2000). Teaching and Learning in the Language Classroom. Oxford: Oxford University Press.

Hutchinson, T. \& Torres, E. (1994). The Textbook as Agent of Change. ELT Journal, 48(4), 315-28.

Ismail, S. A., Dorner, D. \& Oliver, G. (2011). Issues Related to Information Literacy: Education in Malaysian Schools. International Conference on Socialityy \& Economics Development, IPEDR, 10.

Jalaluddin, N. H., Norsimah, M. A. \& Kesumawati, A. B. (2008). The Mastery of English Language Among Lower Secondary School Students in Malaysia: A Linguistic Analysis. European Journal of Social Sciences, 7(2).

Jardine, D. W. (2006). Piaget and Education Primer. New York, NY: Peter Lang Publishing.

Koh, T. D. (2014). English 1119 SPM. Petaling Jaya: Sasbadi Sdn. Bhd.

Lee, M. N. N. (2002). Educational Change in Malaysia. Malaysia: Sinaran Bros. Sdn. Bhd.

Litz, D.R. (2005). Textbook Evaluation \& ELT Management: A South Korean Case Study. Asian ELT Journal, 6(4)

Lee, A., Roberts, L. \& Chew, M. (16th ed.).(Ed.).(2013). English Form 4. Johor: PGI Cipta Sdn. Bhd.

Lee, A., Roberts, L. \& Chew, M. (9th ed.).(Ed.).(2013). English Form 5. Johor: PGI Cipta Sdn. Bhd.

Littlejohn, A. (1998). The Analysis of Language Teaching Materials: Inside the Trojan Horse. In B. Tomlinson. (ed.), ( $2^{\text {nd }}$ ed.). Materials Development in Language Teaching (pp.191-213). Cambridge: Cambridge University Press.

Madziah, A., Sarudin, I., Nordin, M. S. \& Ahmad, B. (2011). English Competency for Entry-Level Employment: A market research on industrial needs. Kuala Lumpur: Prestariang Systems Sdn. Bhd.

Maley, A. (1998). Squaring the Circle - Reconciling Materials as Constraint with Materials as Empowerment. In B. Tomlinson (ed.), (2nd ed.). Materials Development in Language Teaching (pp. 379-402). Cambridge: Cambridge University Press.

Masuhara, H. (2011). What do Teachers Really Want From Coursebooks? In B. Tomlinson (Ed.), (2nd ed.). Materials Development in Language Teaching (pp. 236-266). Cambridge: Cambridge University Press.

McDonough, J. \& Shaw, C. (2nd ed.). (2003). Materials and Methods in ELT. Oxford: Blackwell.

McGrath, I. (2002). Materials Evaluation and Design for Language Teaching. Edinburgh: Edinburgh University Press.

McGrath, I. (2006). Teachers' and Learners' Images for Coursebooks. ELT Journal 60(2), 171-180.

Ministry of Education of Malaysia. (1999). Belejar Cara Belajar (Learn How To Learn). Kuala Lumpur: Curriculum Development Centre (CDC).

Ministry of Education of Malaysia. (2003). Malaysia Curriculum Specifications for English Language Form 4. Kuala Lumpur. 
Ministry of Education of Malaysia. (2003). Malaysia Curriculum Specifications for English Language Form 5. Kuala Lumpur.

Ministry of Education of Malaysia. (2012). Malaysia Education Blueprint. Kuala Lumpur.

Ministry of Education of Malaysia. (2014). Usage of Textbooks. Retrieved from

http://web.moe.gov.my/bbt/penggunaan_program_en.php on 13 July, 2014.

Mukundan, J. (2003). Readings on ELT Material. Kuala Lumpur: Universiti Putra Malaysia Press.

Mukundan, J. \& Ahour, T. (2010). A Review of Textbook Evaluation Checklists Across Four Decades (1970-2008). In B. Tomlinson \& H. Masuhara (Eds.), Research for Materials Development in Language Learning: Evidence for Best Practice (pp. 336-352). London: Continuum.

Mukundan, J. (2011). Developing an English Language Textbook Evaluation Checklist: A Focus Group Study. International Journal of Humanities and Social Science, 1(12), 100-106.

Mukundan, J. Hajimohammadi, R. \& Nimehchisalem, V. (2011). Developing An English Language Textbook Evaluation Checklist. Contemporary Issues In Education Research, 4(6), 21-28.

Mukundan, J. \& Nimehchisalem, V. (2012). Evaluative Criteria of an English Language Textbook Evaluation Checklist. Journal of Language Teaching \& Research, 3(6), 1128-1134.

Mukundan, J. \& Rezvani Kalajahi, S.A. (2013). Evaluation of Malaysian English Language Teaching Textbooks. International Journal of Education \& Literacy Studies, $1(1), \quad 38-46$. O’Neill, R. (1982). Why Use Textbooks? ELT Journal, 36(2), 104-11.

O’Neill, R. (1993). Are Textbook Symptoms of a Disease? Practical English Teaching, 14(1), 11-13.

Paltridge, B. \& Phakiti, A. (2010). Continuum Companion to Research Methods in Applied Linguistics. London: Continuum International Publishing Group.

Prabu, N.S. (1997). Second Language Pedagogy: Vol. 20. Oxford: Oxford University Press.

Riazi, A. M. (2003). What Do Textbook Evaluation Schemes Tell Us? A Study of the Textbook Evaluation schemes of Three Decades. In W.A. Renandya. (Ed.). Methodology and Materials Design in Language Teaching: Current Perceptions and Practices and Their Implications (pp. 52-69). Singapore: RELC Portfolio Series.

Richards, J. (1998). Textbooks: Help or Hindrance in Teaching? In J. Richards, Beyond Training: Perspectives on Language Teacher Education (pp. 125-141). Cambridge: Cambridge University Press.

Richards, J. C., \& Rodgers, T. S. (2001). Approaches and Methods in Language Teaching (2nd ed.). Cambridge: Cambridge University Press.

Richards, J. C. (2012). Advantages and Disadvantages of Using Instructional Materials in Teaching ESL. The Official Website of Applied Linguist Dr. Jack C. Richards. Retrieved from http://www.professorjackrichards.com/advantagesand-disadvantages-of-using-instructional-materials-in-teaching-esl/ on August 5, 2014.

Samah, A. A. (1984). The English Language (communicational) Curriculum for Upper Secondary Schools in Malaysia: Rationale, Design and Implementation. In J.A.S. Read (Ed.), Trends in English Language Syllabus Design (pp. 193214). Singapore: Singapore University Press.

Sarudin, I., Zubairi, A. M., Nordin, M.S. \& Omar, M.A. (2008). The English Language Proficiency of Malaysian Public University Students. In Md Yurof Abu Bakar, Nor Eieni Hj Mokhtar, Rohana Jani, Ainol Madziah Zubairi, Norasma Othman and Aries Gan (Eds.), Enhancing the Quality of Higher Education through Research: Shaping Future Policy (pp. 40-65). Kuala Lumpur: Ministry of Higher Education.

Savignon, J.S. (2001). Communicative Language Teaching for the Twenty-First Century. In M.Celce-Murcia (3rd ed.).(Ed.). Teaching English as a Second or Foreign Language (pp. 13-28). London: Heinle \& Heinle.

Sheldon, L. (1998). Evaluating ELT Textbooks and Materials. ELT Journal, 42(4), 237-246.

Socio-economic \& Environmental Research Institute. (2005). Penang Statistics First Quarter. Penang State Government.

Stoller, F. L. (2004). 12. CONTENT-BASED INSTRUCTION: PERSPECTIVES ON CURRICULUM PLANNING. Annual Review of Applied Linguistics, 24(1), 261-283.

Swales, J. (1990). ESP: The Textbook Problem. The ESP Journal, 1(1), 11-23.

Thornbury, S. (2000). A Dogma for EFL. IATEFL Issues, 153(2).

Tomlinson, B. (1998). Glossary of Basic Terms for Materials Development in Language Teaching. In B. Tomlinson (Ed.) Developing Materials for Language Teaching (pp. ix-xiix). London: Continuum.

Tomlinson, B. (2001). Materials Development. In R. Carter \& D. Nunan, The Cambridge Guide to Teaching English to Speakers of Other Languages (pp. 66-71). Cambridge: Cambridge University Press.

Tomlinson, B. (2003). Humanising the Coursebook. In W.A. Renandya. (Ed.). Methodology and Materials Design in Language Teaching: Current Perceptions and Practices and Their Implications (pp.12-29). Singapore: RELC Portfolio Series. 
Tomlinson, B. \& Masuhara, H. (2004). Developing Language Course Materials. Singapore: RELC Portfolio Series.

Tomlinson, B. 2008). English Language Learning Materials (Ed.). London: Continuum.

Tomlinson, B. (2010). What Do Teachers Think Coursebooks? Modern English Teacher 19(4), 5-9.

Tomlinson, B. (2012). Materials Development for Language Learning \& Teaching. Language Teaching, 45(2), 143179.

Tucker, C.A. (1975). Evaluating Beginning Textbooks. English Teaching Forum, 13(3/4), 355-361.

Ur, P. (1996). A Course in Language Teaching. Cambridge: Cambridge University Press.

Ur, P. (1999). A Course in Language Teaching. Stuttgart: Ernst Klett Sprachen.

Wakeman, S. (2005). Malaysia English Textbook for Malaysian Learners of English. Language in India. Retrieved from http://www.languageinindia.com/june2005/wakemanmalaysiatesol2.html on June 6, 2014.

Yaakob, U. H. \& Norliati, F. M. N. (2013). The Process \& Effects of Demographic Transition in Penang, Malaysia. Kajian Malaysia, 31(2), 37-64.

Yong, F. N. (2014). English SPM Form 4 \& 5. Johor: Pelangi Sdn. Bhd.

\section{Appendix A - Checklist for Textbook Evaluation}

\section{ENGLISH LANGUAGE TEACHING TEXTBOOK CHECKLIST}

I. General attributes

A. The book in relation to syllabus and curriculum

\begin{tabular}{|l|l|l|l|l|l|}
\hline $\begin{array}{l}\text { 1. It matches to the } \\
\text { specifications of the } \\
\text { syllabus. }\end{array}$ & 0 & 1 & 2 & 3 & 4 \\
\hline B. Methodology
\end{tabular}

\begin{tabular}{|l|l|l|l|l|l|}
\hline $\begin{array}{l}\text { 2. The activities can be } \\
\text { exploited fully and can } \\
\text { embrace the various } \\
\text { methodologies in ELT. }\end{array}$ & 0 & 1 & 2 & 3 & 4 \\
\hline $\begin{array}{l}\text { 3. Activities can work } \\
\text { well with } \\
\text { methodologies in ELT. }\end{array}$ & 0 & 1 & 2 & 3 & 4 \\
\hline
\end{tabular}

C. Suitability to learners

\begin{tabular}{|l|l|l|l|l|l|}
\hline $\begin{array}{l}\text { 4. It is compatible to } \\
\text { the age of the learners. }\end{array}$ & 0 & 1 & 2 & 3 & 4 \\
\hline $\begin{array}{l}\text { 5. It is compatible to } \\
\text { the needs of the } \\
\text { learners. }\end{array}$ & 0 & 1 & 2 & 3 & 4 \\
\hline $\begin{array}{l}\text { D. Physical and utilitarian attributes } \\
\begin{array}{l}\text { 6. Its layout (including } \\
\text { artwork, typefaces, } \\
\text { colour) is attractive. }\end{array}\end{array}$ & 0 & 1 & 2 & 3 & 4 \\
\hline
\end{tabular}




\begin{tabular}{|c|c|c|c|c|c|}
\hline $\begin{array}{l}\text { 7. It indicates efficient } \\
\text { use of text and visuals. }\end{array}$ & 0 & 1 & 2 & 3 & 4 \\
\hline 8. It is durable. & 0 & 1 & 2 & 3 & 4 \\
\hline 9. It is cost-effective. & 0 & 1 & 2 & 3 & 4 \\
\hline \multicolumn{6}{|c|}{ E. Efficient outlay of supplementary materials } \\
\hline $\begin{array}{l}10 . \text { The book is } \\
\text { supported efficiently by } \\
\text { essentials like teacher's } \\
\text { book \& audio- } \\
\text { materials. }\end{array}$ & 0 & 1 & 2 & 3 & 4 \\
\hline \multicolumn{6}{|c|}{$\begin{array}{l}\text { II. Learning-teaching content } \\
\text { A. General }\end{array}$} \\
\hline $\begin{array}{l}\text { 11. Tasks move from } \\
\text { simple to complex. }\end{array}$ & 0 & 1 & 2 & 3 & 4 \\
\hline $\begin{array}{l}\text { 12. Task objectives are } \\
\text { achievable. }\end{array}$ & 0 & 1 & 2 & 3 & 4 \\
\hline $\begin{array}{l}\text { 13. Cultural } \\
\text { sensitivities have been } \\
\text { considered. }\end{array}$ & 0 & 1 & 2 & 3 & 4 \\
\hline $\begin{array}{l}\text { 14. The language in the } \\
\text { textbook is natural and } \\
\text { real. }\end{array}$ & 0 & 1 & 2 & 3 & 4 \\
\hline $\begin{array}{l}\text { 15. The situations } \\
\text { created in the dialogues } \\
\text { sound natural and real. }\end{array}$ & 0 & 1 & 2 & 3 & 4 \\
\hline \multicolumn{6}{|l|}{ B. Listening } \\
\hline $\begin{array}{l}\text { 16. The book has } \\
\text { appropriate listening } \\
\text { tasks with well-defined } \\
\text { goals. }\end{array}$ & 0 & 1 & 2 & 3 & 4 \\
\hline $\begin{array}{l}\text { 17. Tasks are efficiently } \\
\text { graded according to } \\
\text { complexity. }\end{array}$ & 0 & 1 & 2 & 3 & 4 \\
\hline $\begin{array}{l}\text { 18. Tasks are authentic } \\
\text { or close to real } \\
\text { language situations. }\end{array}$ & 0 & 1 & 2 & 3 & 4 \\
\hline \multicolumn{6}{|l|}{ C. Speaking } \\
\hline $\begin{array}{l}\text { 19. Activities are } \\
\text { developed to initiate } \\
\text { meaningful } \\
\text { communication. }\end{array}$ & 0 & 1 & 2 & 3 & 4 \\
\hline
\end{tabular}




\begin{tabular}{|c|c|c|c|c|c|}
\hline $\begin{array}{l}\text { 20. Activities are } \\
\text { balanced between } \\
\text { individual response, } \\
\text { pair work and group } \\
\text { work. }\end{array}$ & 0 & 1 & 2 & 3 & 4 \\
\hline \multicolumn{6}{|l|}{ D. Reading } \\
\hline 21. Texts are graded. & 0 & 1 & 2 & 3 & 4 \\
\hline $\begin{array}{l}\text { 22. Texts are } \\
\text { interesting. }\end{array}$ & 0 & 1 & 2 & 3 & 4 \\
\hline \multicolumn{6}{|l|}{ E. Writing } \\
\hline $\begin{array}{l}\text { 23. Tasks have } \\
\text { achievable goals and } \\
\text { take into consideration } \\
\text { learner capabilities. }\end{array}$ & 0 & 1 & 2 & 3 & 4 \\
\hline $\begin{array}{l}\text { 24. Tasks are } \\
\text { interesting. }\end{array}$ & 0 & 1 & 2 & 3 & 4 \\
\hline \multicolumn{6}{|l|}{ F. Vocabulary } \\
\hline $\begin{array}{l}25 . \text { The load (number } \\
\text { of new words in each } \\
\text { lesson) is appropriate to } \\
\text { the level. }\end{array}$ & 0 & 1 & 2 & 3 & 4 \\
\hline $\begin{array}{l}\text { 26. There is a good } \\
\text { distribution (simple to } \\
\text { complex) of vocabulary } \\
\text { load across chapters } \\
\text { and the whole book. }\end{array}$ & 0 & 1 & 2 & 3 & 4 \\
\hline $\begin{array}{l}27 . \text { Words are } \\
\text { efficiently repeated and } \\
\text { recycled across the } \\
\text { book. }\end{array}$ & 0 & 1 & 2 & 3 & 4 \\
\hline \multicolumn{6}{|l|}{ G. Grammar } \\
\hline $\begin{array}{l}28 . \text { The spread of } \\
\text { grammar is achievable. }\end{array}$ & 0 & 1 & 2 & 3 & 4 \\
\hline $\begin{array}{l}29 \text {. The grammar is } \\
\text { contextualized. }\end{array}$ & 0 & 1 & 2 & 3 & 4 \\
\hline $\begin{array}{l}\text { 30. Examples are } \\
\text { interesting. }\end{array}$ & 0 & 1 & 2 & 3 & 4 \\
\hline $\begin{array}{l}\text { 31. Grammar is } \\
\text { introduced explicitly } \\
\text { and reworked } \\
\text { incidentally throughout } \\
\text { the book. }\end{array}$ & 0 & 1 & 2 & 3 & 4 \\
\hline \multicolumn{6}{|l|}{ H. Pronunciation } \\
\hline $\begin{array}{l}\text { 32. It is } \\
\text { contextualized. }\end{array}$ & & 1 & 2 & 3 & 4 \\
\hline
\end{tabular}




\begin{tabular}{|c|c|c|c|c|c|}
\hline $\begin{array}{l}\text { 33. It is learner- } \\
\text { friendly with no } \\
\text { complex charts. }\end{array}$ & 0 & 1 & 2 & 3 & 4 \\
\hline \multicolumn{6}{|l|}{ I. Exercises } \\
\hline $\begin{array}{l}\text { 34. They are } \\
\text { learner friendly. }\end{array}$ & 0 & 1 & 2 & 3 & 4 \\
\hline $\begin{array}{l}\text { 35. They are } \\
\text { adequate. }\end{array}$ & 0 & 1 & 2 & 3 & 4 \\
\hline $\begin{array}{l}\text { 36. They help } \\
\text { students who } \\
\text { are under/over- } \\
\text { achievers. }\end{array}$ & 0 & 1 & 2 & 3 & 4 \\
\hline
\end{tabular}

Source: Mukundan and Nimechisalem (2012: 1132)

\section{Appendix B - Formation of Interview Questions}

The interview questions were formed with reference to the outcome of the checklists for both forms 4 and 5 . As the interview is used as an informant step to provide suggestions from teachers to adapt textbooks, the questions are phrased to elicit as much information from the teachers as possible. In both the checklists outlined by Cunningsworth (1995) and Sheldon (1988), the general criteria of 'sufficiency', 'methodology', 'suitability to learners', 'learningteaching content', 'utilitarian', 'efficient outlay of supplementary materials', 'speaking', 'writing', 'listening', 'role of teacher' and 'suggestions of improvement' are included. This is as the general criteria are in accordance with the type of responses needed to be elicited from teachers for suggestions to modify the form 4,5 textbooks.

From the general criteria, questions that complement the findings from the checklists will be picked and modified to further suit the current context. The original questionnaires from Cunningsworth (1995) and Sheldon (1988) are attached in appendices $\mathrm{H}$ and I. Below is the preliminary set of questions with the sections of checklists that they were drafted from.

$\underline{\text { Preliminary set of questions }}$

Sufficiency (Sheldon: Suffiency: Question 1):

Is the textbook complete enough to stand on its own or must you - the teacher produce additional material?

Methodology: (Cunningsworth: Methodology: Question 1):

What approach/approaches to language learning are taken by the textbook?

Suitability to learners (Cunningsworth: Checklist for learner needs: Question 9):

Can the textbook accommodate all the different learning styles?

(Sheldon: Flexibility: Question 2): If not can it be adapted to suit the different needs of students?

Grading (Sheldon: Selection/grading: Question 2):

Are the three levels of difficulty grading on tasks helpful?

Degree of imposition (Sheldon: Flexibility: Question 1):

Do the textbook make demands on teachers' preparation time and students' homework time? 
Sufficiency (Cunningsworth: Language development. Skills: Questions 1, 3):

Are all skills equally covered?

Is there any skill/s which is/are omitted, and how can that be improved?

Supplementary materials (Cunningsworth: Checklist for listening: Question 6)

Are the audio/visual materials up to par in terms of sound quality, speed of delivery, accent and authenticity?

Speaking (Cunningsworth: Checklist for speaking: Questions 4,5):

How do you think the exercises serve to improve students' speaking abilities?

What do you suggest to improve on?

Writing (Cunningsworth: Checklist for writing: Question 8):

How has the writing exercises improve students' writing abilities?

What do you suggest to improve on?

Listening (Cunningsworth: Checklist for listening: Questions 1,3):

Are the activities sufficient and helpful towards students' learning?

Role of teacher (Cunningsworth: Teachers' book: Question 4):

Does the textbook see the teacher's role as that of: guide, facilitator, manager of learning, director, monitor?

Suggestions of improvement:

How can the textbook be improved? (In cost and durability, recycling of vocabulary, illustration/layout?)

Is there anything else you would like to add that you think did not provide by the checklist? Is there anything you would like to explain in detail pertaining to what was discussed?

\section{Revised Questions for Interview:}

After the feedback from my supervisor, the questions were revised for comprehensiveness and conciseness with two more questions (literature and exam related) added in.

1. Sufficiency: Is the textbook complete enough to stand on its own or must you - the teacher produce additional material?

2. Methodology: What approach/approaches to language learning are taken by the textbook?

3. Suitability to learners: Can the textbook accommodate all the different learning styles? If not can it be adapted to suit different needs of students? 
4. Learning-teaching content: Are the three levels of difficulty grading on tasks helpful? For the weak/strong students?

5. Utilitarian: Do the textbook make demands on teachers' preparation time? In what ways are they time consuming? What demands do they make on you as a teacher? and what about the students' homework time?

6. Learning - teaching content: Are all the four skills of reading, writing, listening and speaking equally covered? Is there any skill/s which is/are omitted, and how can that be improved?

7. Efficient outlay of supplementary materials: Are the audio/visual materials up to par in terms of sound quality, speed of delivery, accent? Is the conversation authentic? Are there speakers of different nationalities voicing the scripts? (For listening and pronunciation)

8. Speaking: Do you think the exercises help to improve students' speaking skills? What do you suggest (the exercises) to improve on?

9. Writing: Do you think the writing exercises improve students' writing skills? What do you suggest (the exercises) to improve on?

10. Listening: Are the activities sufficient to the students? Are they helpful towards their learning of the skill?

11. Role of teacher: How does the textbook see the role of the teacher? (To suggest if the teacher has no answer: Is it as a guide, facilitator, manager of learning, director, monitor?)

12. Suggestions of improvement: How can the textbook be improved? (For example in cost and durability, recycling of vocabulary, illustration/layout ...depending on the teacher's responses in the checklist)

13. What is your opinion on the literature section of the textbook? Do you think it should be included in the book or should it be a separate section of its own?

14. Does the material prepare students for the examination?

15. Is there anything else you would like to add that you think did not provide by the checklist (e.g. sufficiency of the book in accordance to the assessment and the periods required to finish the book? Is there anything you would like to explain in detail pertaining to what was discussed?

\section{Appendix C - Interview Questions}

1. Sufficiency: Is the textbook complete enough to stand on its own or must you - the teacher produce additional material?

2. Methodology: What approach/approaches to language learning are taken by the textbook?

3. Suitability to learners: Can the textbook accommodate all the different learning styles? If not can it be adapted to suit different needs of students?

4. Learning-teaching content: Are the three levels of difficulty grading on tasks helpful? For the weak/strong students?

5. Utilitarian: Do the textbook make demands on teachers' preparation time? In what ways are they time consuming? What demands do they make on you as a teacher? and what about the students' homework time?

6. Learning - teaching content: Are all the four skills of reading, writing, listening and speaking equally covered? Is there any skill/s which is/are omitted, and how can that be improved?

7. Efficient outlay of supplementary materials: Are the audio/visual materials up to par in terms of sound quality, speed of delivery, accent? Is the conversation authentic? Are there speakers of different nationalities voicing the scripts? (For listening and pronunciation)

8. Speaking: Do you think the exercises help to improve students' speaking skills? What do you suggest (the exercises) to improve on? 
9. Writing: Do you think the writing exercises improve students' writing skills? What do you suggest (the exercises) to improve on?

10. Listening: Are the activities sufficient to the students? Are they helpful towards their learning of the skill?

11. Role of teacher: How does the textbook see the role of the teacher? (To suggest if the teacher has no answer: Is it as a guide, facilitator, manager of learning, director, monitor?)

12. Suggestions of improvement: How can the textbook be improved? (For example in cost and durability, recycling of vocabulary, illustration/layout ... depending on the teacher's responses in the checklist)

13. What is your opinion on the literature section of the textbook? Do you think it should be included in the book or should it be a separate section of its own?

14. Does the material prepare students for the examination?

15. Is there anything else you would like to add that you think did not provide by the checklist (e.g. sufficiency of the book in accordance to the assessment and the periods required to finish the book? Is there anything you would like to explain in detail pertaining to what was discussed?

\section{Appendix D - Form 4 and 5 Teachers' Responses to Textbook Evaluation Checklist}

Below are the responses of the eighteen teachers surveyed marked in tick $(\checkmark)$ for Form 5 teachers and crosses $(X)$ for Form 4's. In accordance to the evaluating criteria presented to the teachers, the scale of (0-4) is used to indicate the level of importance of each criterion. The key is explained as follows:
0: Unimportant
1: Less important
2: Fairly important
3: Important
4: Very Important

A similar score is given from the scale, for example a scale of 1 will carry a score of 1 . The combined scores are then divided by the number of participants, which is nine for each group, to give the average score. The average score guide is as follows:

0 : Very poorly favourable 1 : Poorly favourable favourable 4: Very highly favourable

\section{ENGLISH LANGUAGE TEACHING TEXTBOOK CHECKLIST}

\begin{tabular}{|c|c|c|c|c|c|c|}
\hline \multicolumn{6}{|c|}{$\begin{array}{l}\text { I. General attributes } \\
\text { A. The book in relation to syllabus and curriculum }\end{array}$} & \multirow{2}{*}{$\begin{array}{c}\text { Average } \\
\text { scores } \\
3 \\
3\end{array}$} \\
\hline $\begin{array}{l}\text { 1. It matches to the specifications of the } \\
\text { syllabus. }\end{array}$ & 0 & 1 & $\begin{array}{c}2 \\
\boldsymbol{J} \checkmark \\
x \times\end{array}$ & $\begin{array}{c}3 \\
\boldsymbol{} \\
X \quad \boldsymbol{V} \\
X\end{array}$ & $\begin{array}{c}4 \\
\checkmark \checkmark \checkmark \\
X \times\end{array}$ & \\
\hline \multicolumn{7}{|l|}{ B. Methodology } \\
\hline $\begin{array}{l}\text { 2. The activities can be exploited fully and } \\
\text { can embrace the various methodologies in } \\
\text { ELT. }\end{array}$ & 0 & 1 & $\begin{array}{c}2 \\
\checkmark \\
\times \times x\end{array}$ & $\begin{array}{c}3 \\
\checkmark \\
\checkmark \\
\checkmark \\
X \\
X X X \\
x\end{array}$ & $\begin{array}{l}4 \\
\checkmark \checkmark \\
x\end{array}$ & 3 \\
\hline $\begin{array}{l}\text { 3. Activities can work well with } \\
\text { methodologies in ELT. }\end{array}$ & 0 & $X$ & X X & $\begin{array}{c}3 \\
\checkmark \checkmark \checkmark \checkmark \\
\checkmark \checkmark \checkmark \checkmark \\
\checkmark \\
x \times x x \\
x\end{array}$ & 4 & 3 \\
\hline
\end{tabular}




\begin{tabular}{|c|c|c|c|c|c|c|}
\hline \multicolumn{6}{|l|}{ C. Suitability to learners } & \multirow[b]{2}{*}{3} \\
\hline 4. It is compatible to the age of the learners. & $\begin{array}{l}0 \\
X\end{array}$ & 1 & $\begin{array}{c}2 \\
\checkmark \\
\times \times\end{array}$ & $\begin{array}{c}3 \\
\checkmark \checkmark \checkmark \checkmark \\
\checkmark \checkmark \checkmark \\
x \times x \times \\
x\end{array}$ & $\begin{array}{c}4 \\
\qquad \checkmark \\
x\end{array}$ & \\
\hline $\begin{array}{l}\text { 5. It is compatible to the needs of the } \\
\text { learners. }\end{array}$ & 0 & $\begin{array}{l}1 \\
X\end{array}$ & $\begin{array}{l}2 \\
\boldsymbol{J} \\
X \times\end{array}$ & 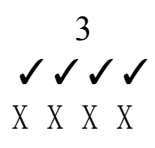 & $\begin{array}{c}4 \\
\checkmark \checkmark \checkmark \\
X \times 1\end{array}$ & $\begin{array}{l}3 \\
3\end{array}$ \\
\hline \multicolumn{7}{|l|}{ D. Physical and utilitarian attributes } \\
\hline 6. Its layout is attractive. & 0 & $\begin{array}{l}1 \\
\text { X X }\end{array}$ & $\begin{array}{l}2 \\
\checkmark \\
X \times\end{array}$ & $\begin{array}{c}3 \\
\checkmark \checkmark \checkmark \\
\checkmark \\
x \times x \times\end{array}$ & $\begin{array}{c}4 \\
\checkmark \checkmark \\
X\end{array}$ & $\begin{array}{l}3 \\
3\end{array}$ \\
\hline $\begin{array}{l}\text { 7. It indicates efficient use of text and } \\
\text { visuals. }\end{array}$ & 0 & 1 & $\begin{array}{l}2 \\
\\
X X X \\
X\end{array}$ & $\begin{array}{c}3 \\
\checkmark \\
\checkmark \\
\checkmark \\
x \times x\end{array}$ & $\begin{array}{c}4 \\
\checkmark \checkmark \checkmark \\
x\end{array}$ & $\begin{array}{l}3 \\
3\end{array}$ \\
\hline 8. It is durable. & 0 & $\begin{array}{l}1 \\
\text { X X }\end{array}$ & $\begin{array}{c}2 \\
\checkmark \\
X X X\end{array}$ & $\begin{array}{c}3 \\
\checkmark \\
\checkmark \\
\checkmark \\
X X\end{array}$ & $\begin{array}{c}4 \\
\qquad \checkmark \\
x\end{array}$ & $\begin{array}{l}3 \\
2\end{array}$ \\
\hline 9. It is cost-effective. & 0 & $\begin{array}{c}1 \\
\checkmark \\
X X\end{array}$ & $\begin{array}{c}2 \\
\checkmark \\
X X\end{array}$ & $\begin{array}{c}3 \\
\checkmark \\
\checkmark \\
\checkmark \\
x \times x\end{array}$ & $\begin{array}{c}4 \\
\checkmark \checkmark \\
X \times\end{array}$ & $\begin{array}{l}3 \\
3\end{array}$ \\
\hline \multicolumn{7}{|l|}{ E. Efficient outlay of supplementary materials } \\
\hline $\begin{array}{l}\text { 10. The book is supported efficiently by } \\
\text { essentials like audio-materials. }\end{array}$ & 0 & $\begin{array}{c}1 \\
X X\end{array}$ & $\begin{array}{c}2 \\
\checkmark \\
X \times X \\
X\end{array}$ & $\begin{array}{c}3 \\
\checkmark \\
\checkmark \\
\checkmark \\
X \times x\end{array}$ & $\stackrel{4}{\checkmark}$ & $\begin{array}{l}3 \\
2\end{array}$ \\
\hline \multicolumn{7}{|l|}{$\begin{array}{l}\text { II. Learning-teaching content } \\
\text { A. General }\end{array}$} \\
\hline 11. Tasks move from simple to complex. & 0 & $\begin{array}{r}1 \\
X\end{array}$ & $\begin{array}{c}2 \\
\checkmark \checkmark \\
X X X\end{array}$ & $\begin{array}{c}3 \\
\triangleleft \checkmark \checkmark \checkmark \\
\checkmark \\
x \times x\end{array}$ & $\begin{array}{ll} & 4 \\
\checkmark & \checkmark \\
x & X\end{array}$ & $\begin{array}{l}3 \\
2\end{array}$ \\
\hline 12. Task objectives are achievable. & 0 & 1 & $\begin{array}{c}\checkmark^{2} \\
x \times\end{array}$ & $\begin{array}{c}3 \\
\mathfrak{d} \checkmark \\
\checkmark \\
\times \sqrt{ } \times \\
x \times\end{array}$ & $\begin{array}{r}4 \\
\checkmark \checkmark \\
X \times\end{array}$ & 3 \\
\hline $\begin{array}{l}\text { 13. Cultural sensitivities have been } \\
\text { considered. }\end{array}$ & 0 & 1 & X X & $\begin{array}{c}3 \\
\checkmark \checkmark \checkmark \checkmark \\
\checkmark \checkmark \checkmark \\
X \times x \times\end{array}$ & $\begin{array}{r}4 \\
\checkmark \checkmark \\
X \times\end{array}$ & 3 \\
\hline
\end{tabular}




\begin{tabular}{|c|c|c|c|c|c|c|}
\hline $\begin{array}{l}\text { 14. The language in the textbook is natural } \\
\text { and real. }\end{array}$ & 0 & 1 & $\begin{array}{l}2 \\
\times X X \\
X\end{array}$ & 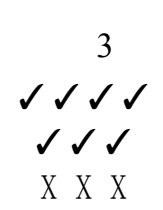 & $\begin{array}{r}4 \\
\checkmark \checkmark \\
\times x\end{array}$ & 3 \\
\hline $\begin{array}{l}\text { 15. The situations created in the dialogues } \\
\text { sound natural and real. }\end{array}$ & 0 & 1 & $\begin{array}{r}2 \\
X X\end{array}$ & $\begin{array}{c}3 \\
\checkmark \checkmark \checkmark \checkmark \\
\checkmark \checkmark \checkmark \checkmark \\
\checkmark \\
x \times x \times \\
x\end{array}$ & X X & 3 \\
\hline \multicolumn{7}{|l|}{ B. Listening } \\
\hline $\begin{array}{l}\text { 16. The book has appropriate listening tasks } \\
\text { with well-defined goals. }\end{array}$ & 0 & $\begin{array}{r}1 \\
X\end{array}$ & $\begin{array}{rl} & 2 \\
\checkmark & \checkmark \\
X & X\end{array}$ & $\begin{array}{c}3 \\
\checkmark \\
\checkmark \\
\checkmark \\
X X X X \\
x\end{array}$ & $\begin{array}{c}4 \\
\checkmark \checkmark \\
X\end{array}$ & $\begin{array}{l}3 \\
3\end{array}$ \\
\hline $\begin{array}{l}\text { 17. Tasks are efficiently graded according to } \\
\text { complexity. }\end{array}$ & 0 & X & $\begin{array}{l}\checkmark^{2} \\
X \times\end{array}$ & $\begin{array}{c}3 \\
\checkmark \checkmark \checkmark \checkmark \\
\checkmark \\
X X X X \\
X \\
\text { X X }\end{array}$ & $\begin{array}{r}4 \\
\qquad 5 \\
x\end{array}$ & 3 \\
\hline $\begin{array}{l}\text { 18. Tasks are authentic or close to real } \\
\text { language situations. }\end{array}$ & 0 & $X$ & $\begin{array}{r}2 \\
X \quad X\end{array}$ & 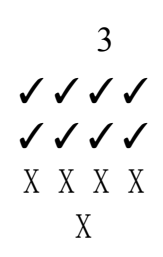 & $\begin{array}{l}4 \\
x\end{array}$ & 3 \\
\hline \multicolumn{7}{|l|}{ C. Speaking } \\
\hline $\begin{array}{l}\text { 19. Activities are developed to initiate } \\
\text { meaningful communication. }\end{array}$ & 0 & X & $\begin{array}{r}2 \\
X \quad X\end{array}$ & $\begin{array}{c}3 \\
\checkmark \checkmark \checkmark \checkmark \\
\checkmark \\
X \times \\
X \times x\end{array}$ & $\begin{array}{c}4 \\
\checkmark \checkmark \checkmark \\
X \times\end{array}$ & 3 \\
\hline $\begin{array}{l}\text { 20. Activities are balanced between } \\
\text { individual response, pair work and group } \\
\text { work. }\end{array}$ & 0 & $X$ & X X & $\begin{array}{r}3 \\
\checkmark \checkmark \checkmark \checkmark \\
\checkmark \checkmark \checkmark \\
x \times x \times\end{array}$ & $\begin{array}{r}4 \\
\checkmark \checkmark \\
\times \times\end{array}$ & 3 \\
\hline \multicolumn{7}{|l|}{ D. Reading } \\
\hline 21. Texts are graded. & 0 & 1 & 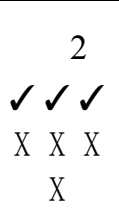 & 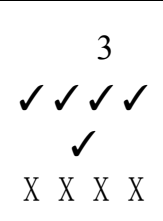 & $\begin{array}{l}4 \\
\checkmark \\
X\end{array}$ & $\begin{array}{l}3 \\
3\end{array}$ \\
\hline 22. Texts are interesting. & 0 & X & $\begin{array}{l}\checkmark^{2} \\
X X\end{array}$ & $\begin{array}{c}3 \\
\checkmark \checkmark \checkmark \\
\checkmark \\
X \times \checkmark \\
X X X\end{array}$ & $\begin{array}{c}4 \\
\checkmark \\
X X\end{array}$ & 3 \\
\hline
\end{tabular}




\section{E. Writing}

23. Tasks have achievable goals and take into consideration learner capabilities.

\begin{tabular}{l|l|l}
0 & 1 \\
0 & 1 \\
& &
\end{tabular}

\section{F. Vocabulary}

\begin{tabular}{|c|c|c|c|c|c|c|}
\hline $\begin{array}{l}\text { 25. The load (number of new words in each } \\
\text { lesson) is appropriate to the level. }\end{array}$ & 0 & 1 & $\begin{array}{l}2 \\
J^{2}\end{array}$ & $\begin{array}{c}3 \\
\checkmark \checkmark \checkmark \\
\checkmark \checkmark \\
X X X X \\
X X X\end{array}$ & $\begin{array}{c}4 \\
\qquad \checkmark\end{array}$ & 3 \\
\hline $\begin{array}{l}\text { 26. There is a good distribution (simple to } \\
\text { complex) of vocabulary load across chapters } \\
\text { and the whole book. }\end{array}$ & 0 & 1 & $\begin{array}{l}\checkmark^{2} \\
X X\end{array}$ & 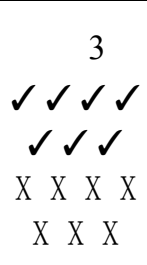 & 4 & 3 \\
\hline $\begin{array}{l}\text { 27. Words are efficiently repeated and } \\
\text { recycled across the book. }\end{array}$ & 0 & 1 & $\begin{array}{l}2 \\
\boldsymbol{J} \\
x \times x \\
x \times x\end{array}$ & 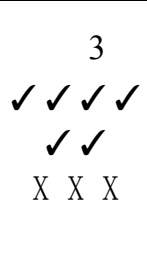 & 4 & 3 \\
\hline \multicolumn{7}{|l|}{ G. Grammar } \\
\hline 28. The spread of grammar is achievable. & 0 & 1 & $\begin{array}{r}2 \\
X \quad X\end{array}$ & 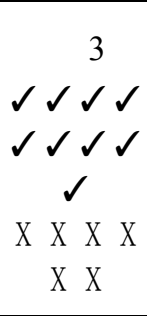 & $\begin{array}{l}4 \\
X\end{array}$ & 3 \\
\hline 29. The grammar is contextualized. & 0 & 1 & $\begin{array}{l}\checkmark^{2} \\
X X\end{array}$ & $\begin{array}{c}3 \\
\checkmark \checkmark \checkmark \checkmark \\
\checkmark \checkmark \checkmark \\
x \times x x \\
x\end{array}$ & $\begin{array}{c}4 \\
\checkmark \\
X \times\end{array}$ & 3 \\
\hline 30. Examples are interesting. & 0 & 1 & $\begin{array}{c}\boldsymbol{J}^{2} \\
X \times x\end{array}$ & $\begin{array}{c}3 \\
\checkmark \checkmark \checkmark \\
\checkmark \\
X \sqrt{ } \times \\
X X X\end{array}$ & $\begin{array}{c}4 \\
\checkmark \\
X \times\end{array}$ & 3 \\
\hline
\end{tabular}




\begin{tabular}{|c|c|c|c|c|c|c|}
\hline $\begin{array}{l}\text { 31. Grammar is introduced explicitly and } \\
\text { reworked incidentally throughout the book. }\end{array}$ & 0 & $\begin{array}{r}1 \\
X\end{array}$ & $\begin{array}{c}\boldsymbol{J}^{2} \\
x \times\end{array}$ & 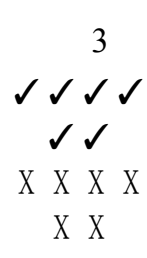 & $\stackrel{4}{\checkmark}$ & 3 \\
\hline \multicolumn{7}{|l|}{ H. Pronunciation } \\
\hline 32. It is contextualized. & 0 & 1 & $\begin{array}{c}\boldsymbol{J}^{2} \\
X X X\end{array}$ & $\begin{array}{c}3 \\
\checkmark \checkmark \checkmark \checkmark \\
\checkmark \checkmark \checkmark \\
X \times x \times \\
x\end{array}$ & $\begin{array}{l}4 \\
\checkmark^{4}\end{array}$ & 3 \\
\hline $\begin{array}{l}\text { 33. It is learner-friendly with no complex } \\
\text { charts. }\end{array}$ & 0 & 1 & $\begin{array}{l}\boldsymbol{J}^{2} \\
x \times\end{array}$ & 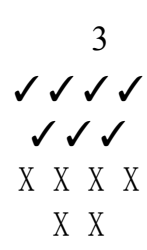 & $\begin{array}{l}4 \\
\checkmark^{4}\end{array}$ & 3 \\
\hline \multicolumn{7}{|l|}{ I. Exercises } \\
\hline 34. They are learner friendly. & 0 & 1 & $\begin{array}{c}\boldsymbol{J}^{2} \\
X \times X\end{array}$ & $\begin{array}{c}3 \\
\checkmark \checkmark \checkmark \checkmark \\
\checkmark \checkmark \checkmark \\
X X X X \\
X\end{array}$ & $\begin{array}{l}4 \\
\checkmark^{4}\end{array}$ & 3 \\
\hline 35. They are adequate. & 0 & 1 & $\begin{array}{l}2 \\
\checkmark \checkmark \\
X X X \\
X X\end{array}$ & $\begin{array}{c}3 \\
\checkmark \checkmark \checkmark \checkmark \\
\checkmark \checkmark \\
X \times X\end{array}$ & $\begin{array}{l}4 \\
\boldsymbol{J}^{4}\end{array}$ & 3 \\
\hline $\begin{array}{l}\text { 36. They help students who are under/over- } \\
\text { achievers. }\end{array}$ & 0 & 1 & $\begin{array}{l}2 \\
\checkmark \checkmark \\
X X X \\
X X X\end{array}$ & 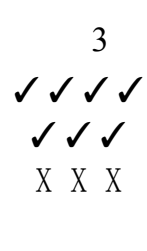 & 4 & 3 \\
\hline
\end{tabular}

Source: Mukundan and Nimechisalem (2012: 1132) 